Costume et déguisement dans le théâtre de Shakespeare et de ses contemporains

\title{
Sartorial Economies and Suitable Style: Woodstock and Shakespeare's Richard II
}

\section{Karen Newman}

\section{(2) OpenEdition Journals}

Electronic version

URL: http://journals.openedition.org/shakespeare/1461

DOI: $10.4000 /$ shakespeare.1461

ISSN: 2271-6424

Publisher

Société Française Shakespeare

\section{Printed version}

Date of publication: 20 December 2008

Number of pages: $71-86$

ISBN: 2-9521475-5-8

\section{Electronic reference}

Karen Newman, «Sartorial Economies and Suitable Style: Woodstock and Shakespeare's Richard II », Actes des congrès de la Société française Shakespeare [Online], 26 | 2008, Online since 20 December 2008, connection on 01 May 2019. URL : http://journals.openedition.org/shakespeare/1461 ; DOI : $10.4000 /$ shakespeare.1461 


\section{Costume et déguisement dans le théâtre de Shakespeare et de ses contemporains}

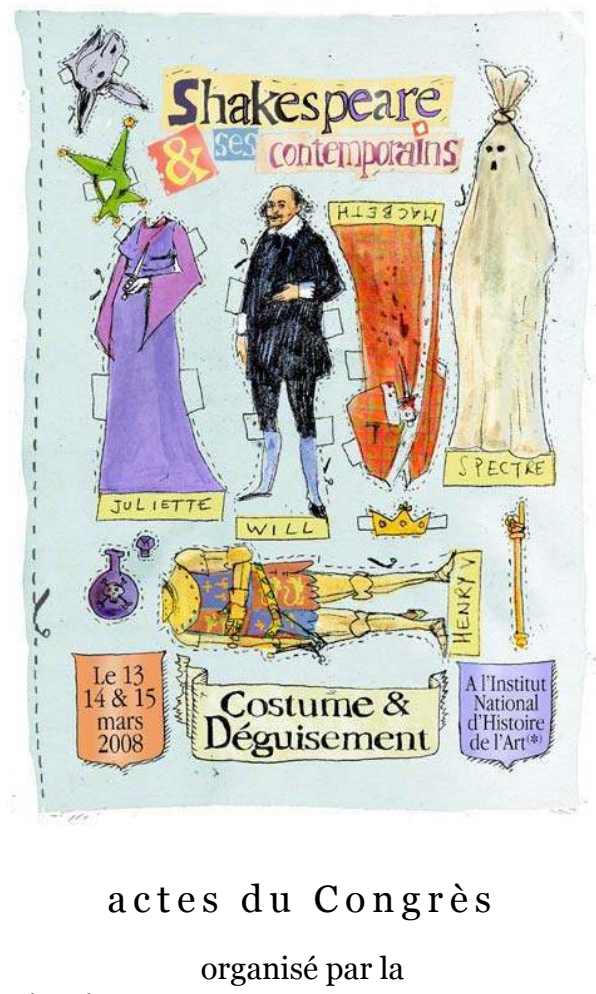

SOCIÉTÉ FRANÇAISE SHAKESPEARE

les 13,14 et 15 mars 2008

textes réunis par

Pierre KAPITANIAK

sous la direction de

Jean-Michel DÉPRATS 
COUVERTURE :

Edouard Lekston,

William en carton et ses habits à découper, 2008 edlek@free.fr

conception graphique et logo

Pierre Kapitaniak

\section{(C) 2008 Société Française Shakespeare}

Institut du Monde Anglophone

Université de Paris III - Sorbonne Nouvelle

5 rue de l'École de Médecine

75006 Paris

www.societefrancaiseshakespeare.org

Tous droits de traduction, de reproduction et d'adaptation réservés pour tous les pays 


\title{
SARTORIAL ECONOMIES AND SUITABLE STYLE: W OODSTOCK AND SHAKESPEARE'S RICHARD II
}

\author{
Karen NEWMAN
}

Clothing plays an important symbolic role in Shakespeare's Richard II and the anonymous Woodstock with which it is often linked. Recent work on dress and clothing in Elizabethan and Jacobean England has focused on sartorial extravagance, on the development of fashion, on conspicuous consumption among the elite, and on fashion trespassing by actors and the socially aspirant. How the majority of the population, which experienced downward mobility and for whom fashion was inaccessible, dressed has been largely ignored. In Act I of Richard II, when Bushy enters announcing that Gaunt is grievous sick, the king notoriously wishes him quickly dead in order to finance the wars in Ireland: "the lining of his coffers shall make coats / To deck our soldiers for these Irish wars" (60-61). Richard's soldiers are in need of coats, as the poor so frequently were in Richard's day, and as they were in England in the sixteenth and seventeenth centuries. What can be said about sartoria economy, even sartorial penury, in early modern English culture? This paper considers unfashionable clothing, the coarse shirts and smocks, loose coats and jerkins, rough bands and hose, of russet, kersey, buckram, homespun, buff and scotch cloth, frieze and indifferent knit, that were the common dress of the large majority of the early modern English population occasionally represented on the English stage.

Les vêtements jouent un rôle symbolique important dans le Richard II de Shakespeare et dans l'anonyme Woodstock. De récents travaux sur les vêtements et les costumes dans l'Angleterre élisabéthaine et jacobéenne se sont penchés sur l'extravagance vestimentaire, sur le développement de la mode, sur la consommation ostentatoire au sein de l'élite et sur la façon dont les acteurs et les arrivistes enfreignaient les codes vestimentaires. En revanche, la façon dont s'habillait la majeure partie de la population, qui subissait une mobilité sociale descendante et pour qui la mode était inaccessible, a été largement ignorée. A l'acte I de Richard II, lorsque Bushy annonce que Gaunt est très malade, le roi souhaite qu'il meure vite pour pouvoir financer la guerre en Irlande. Les soldats de Richard ont besoin de manteaux, comme souvent les pauvres à son époque ou ceux de l'Angleterre des XVI et XVII siècles. Que dire de l'économie vestimentaire, voire de la pénurie vestimentaire dans la culture anglaise renaissante? Cet article examine les innombrables vêtements bien loin de la mode, comme les chemises et les sarraus, les pourpoints et les chausses, qui habillaient la grande majorité de la population anglaise représentée à l'occasion sur scène.

$\mathrm{T}$ hough the clothing of the elite in early modern England has recently received a great deal of critical attention, the clothing of the poor and its symbolic function on the Elizabethan stage have been largely ignored. In what follows, I attempt to redress that neglect by considering the clothing of the non-elite in Shakespeare's Richard II and the anonymous Woodstock, a play which tells the story of Thomas of Woodstock, Duke of Gloucester, whose murder precipitates the conflict between Bolingbroke and Mowbray with which Shakespeare's play opens. My interest, then, is not in costume in the sense of the dress or "get up" of an actor in the theatre, but costume in its primary sense: the mode or fashion of personal attire characteristic of a particular nation, class and period. 
At I.iv of Richard II, the King's decision to go, as he puts it, "in person" to these Irish wars, is framed by two moments in which clothing plays an important symbolic role. First, the king recounts how Bolingbroke leaves London to banishment abroad courting the common people, "wooing poor craftsmen with the craft of smiles" and doffing "his bonnet to an oyster-wench" as if he were "our subjects' next degree in hope". ${ }^{1}$ Bolingbroke's doffed bonnet points up clothing's role in showing deference and status in social relations. In doffing his cap to a street crier, Bolingbroke reverses conventional status hierarchies. Second, as commentators always note, when Bushy enters announcing that Gaunt is grievous sick, Richard wishes him quickly dead in order to finance "these Irish wars". But the specificity of his words is rarely noted: "The lining of his coffers shall make coats / To deck our soldiers for these Irish wars" (61-62). ${ }^{2}$ Coats and coffers, alliteration and syntactical symmetry, draw attention to the cost of clothing in early modern England. The metaphor for Gaunt's wealththe lining of his coffers-extends the sartorial image since the first meaning of "lining" is "the stuff with which garments are lined; the inner or under surface of material stitched into coat, robe, hat, etc. for protection or warmth", a meaning in use at least since the beginning of the fifteenth century.

Richard's soldiers are in need of coats, as the poor so frequently were in Richard's day, and as they were in England in the sixteenth and seventeenth centuries. At III.iii, returned from Ireland and deserted by his allies, Richard laments his plight standing on the walls of Flint Castle where he pledges to give his jewels for beads, his gorgeous palace for a hermitage, and his "gay apparel for an almsman's gown" (149). How did the poor dress? The soldiers and almsmen, craftsmen and oyster-wenches Richard names in the course of Shakespeare's play? Recent work on dress and clothing in Elizabethan and Jacobean England has focused, as I have already noted, on sartorial extravagance, on the development of fashion, on conspicuous consumption among the elite, and on fashion trespassing by actors and

\footnotetext{
${ }^{1}$ King Richard II, ed. Peter Ure (London and New York: Routledge, 1994), I.iv.28, 31. All references are to this Arden edition.

2 On the clothing of common soldiers, see Henry J. Webb, "Falstaff's Clothes", MLN 59 (1944), 162-64.
} 
the socially aspirant. ${ }^{3}$ How the majority of the population, which experienced downward mobility and for whom fashion was inaccessible, dressed has been largely ignored. ${ }^{4}$ In what follows, I consider unfashionable clothing, the coarse shirts and smocks, loose coats and jerkins, rough bands and hose, of russet, kersey, buckram, homespun, buff and scotch cloth, frieze and indifferent knit, that were the common dress of the large majority of the early modern English population occasionally represented on the English stage. How were such cloth and the clothing made from it registered in English writing of the late sixteenth and early seventeenth centuries? What can be said about the relation of cloth and clothing to style?

The importance of cloth to the English economy has been widely acknowledged. The early Tudor period saw the growth of the cloth trade, especially along the London-Antwerp axis, and the dominance of that trade by the Merchant Adventurers. In Elizabeth's time, the still powerful old cloth industry suffered from competition abroad whenever war, plague or bad harvest disrupted fairs and markets, but the "new draperies", luxury cloth manufactured for export, flourished. ${ }^{5}$ Not only cloth, but clothing itself also played an important role in the English economy. In his Burns Journal, Gregory King estimates spending on clothing at $25 \%$ of national expenditure, as compared with $10 \%$ or less in the twentieth century, and he calculated

3 See among many studies Lawrence Stone, The Crisis of the Aristocracy 1558-1641 (Oxford: Clarendon, 1965); the many studies of Tudor and Jacobean costume by Janet Arnold; Jane Ashelford, Dress in the Age of Elizabeth I (New York: Holmes \& Meier, 1988); Karen Newman, Fashioning Femininity and English Renaissance Drama (Chicago: University of Chicago Press, 1991), chapter 7 and Peter Stallybrass and Ann Rosalind Jones, Renaissance Clothing and the Materials of Memory (Cambridge: C.U.P., 2000). On sartorial extravagance, see also Kaja Silverman, "Fragments of a Fashionable Discourse", Studies in Entertainment: Critical Approaches to Mass Culture, ed. Tania Modleski (Bloomington: Indiana University Press, 1986).

4 Keith Wrightson ends his discussion of early modern English population and resources by noting that Gregory King estimated that in 1688 at least half the English population could barely "provide an adequate maintenance for their families. The poor had emerged as a massive and permanent element in English society" (148), English Society 1580-1680 (New Brunswick, NJ: Rutgers University Press, 1982). On downward mobility, see Wrightson, 140-48. See also Wrightson's essay with John Walter, "Dearth and the Social Order in Early Modern England”, Past \& Present 71 (1976), 22-42 and J. D. Chambers, Population, Econom y and Society in Pre-Industrial England (Oxford, 1972).

5 On cloth and the English economy, see Joan Thirsk, Economic Policy and Projects (Oxford: Clarendon, 1978); Margaret Spufford, The Great Reclothing of Rural England (London: Hambledon Press, 1984); and Eric Kerridge, Textile Manufacture in Early Modern England (Manchester: Manchester University Press, 1985); on the "new draperies", see D. C. Coleman, "Innovation and its Diffusion: the "New Draperies", Econom ic History Review 22 (1969) 417-29. 
that some 79 million garments of apparel were added to the national stock annually. Recent work has refined King's figures; N. B. Harte estimates that the poorest spent some $18 \%$ of their annual incomes on clothing, about $£_{3}$, while the better off and very rich spent $28 \%$ and $15 \%$ respectively. ${ }^{6}$

In Shakespeare's England, clothing was real property and a medium of exchange. Social historians have begun to document that importance by looking at household accounts that register the ordering and purchase of clothing, at wills and bequests, in which clothing is passed down to kin and servants, at the widespread practice of "turning", and at the trade in second-hand clothes; they have also studied the availability of clothing outside of London and other English towns through the travels of chapmen; finally, they have examined the rag trade and the high incidence of cloth and clothing theft. ${ }^{7}$ Though in the first chapter of Capital Marx famously argues that gold has become the universal equivalent, he nevertheless registers the continuing economic importance of cloth and clothing obliquely in his choice of commodities, the coat and 20 yards of linen, he uses to demonstrate

\footnotetext{
${ }^{6}$ N. B. Harte, "The Economies of Clothing in the Late Seventeenth-Century", Textile History 22 (1991), 286. Harte's figures are for the late seventeenth century when the stabilization of population growth, agricultural innovation, and improved distribution which resulted in slowly improving real wages apparently enabled a somewhat higher rate of consumption. See also John Hatcher, "Labour, Leisure and Economic Thought before the Nineteenth Century", Past \& Present 160 (1998), 94-95. On the distribution of clothing, or money to redeem clothing in pawn, to the poor, see Linda Hayner, "The Responsibilities of the Parishes of England for the Poor, 1640-1660", Proceedings of the South Carolina Historical Association (1983), 76-84. On the size of the cloth and clothing companies in comparison with other major companies, see Steve Rappaport, World within Worlds: Structures of Life in Sixteenth-Century London (Cambridge: C.U.P., 1989), 394-99, and Jones and Stallybrass, 17, 178, and passim .

${ }^{7}$ See Carole Shammas, The Pre-industrial Consumer in England and America (Oxford: Clarendon, 1990); Harte, cited above; and Lorna Weatherill, "Consumer Behavior, Textiles and Dress in the Late Seventeenth and Early Eighteenth Centuries", Textile History 22 (1991), 277-96 and 297-310 and her Consumer Behaviour and Material Culture in England 1660-1760 (London, 1988); D. C. Coleman, The British Paper Industry 1495-1860 (Oxford: Clarendon, 1958); Donald Woodward, "Swords into Ploughshares: Recycling in Preindustrial England", Economic History Review 38 (1985), 175-191; and F. G. Emmison, Elizabethan Life: Disorder (Chelmsford: Essex Co. Council, 1970) who notes the "scores of indictments for stealing clothes", and whose appendixes document the high incidence of cloth theft. On second hand clothing, see Beverly Lemire, "Consumerism in Preindustrial and Early Industrial England: The Trade in Secondhand Clothes", Journal of British Studies 27 (1988), 1-24; John Styles, "Clothing the North: The Supply of Non-Elite Clothing in the Eighteenth-Century North of England”, Textile History 25 (1994), 139-166, and Jones and Stallybrass, Chapter 1. For contemporary representations of the textile guilds, see The Works of Thomas Deloney, ed. F. O. Mann (Oxford: Clarendon, 1912), particularly Iacke of Newberie and Thomas of Reading.
} 
value and the effacement of labor. The examples of coat and linen in Capital, like recent biographical work on Marx's serial pawning of his own coat, show that cloth and clothing persisted as real property well into the nineteenth century. ${ }^{8}$

That clothing betokens social relations in early modern England is virtually a cliché. As Polonius pompously reminds Laertes, "the apparel oft proclaims the man", (Hamlet, I.iii.72). Clothes make men, or as Spenser put it, "Apparell is comonlye made according to theire Condicions, and theire Condicions are often times gouerned by theire garments". 9 Sumptuary legislation, livery, ballads and pamphlets, diatribes and homilies against excess in apparel, the vestiarian controversy, all testify to the significance of clothes as markers of status, gender, work and religious faith..$^{10}$ In Francis Thynn's didactic poem (c. 1568), The Debate between Pride and Low liness, later pirated by Robert Greene and published in 1592 as Quip for an Upstart Courtier, Thynn catalogues the clothing of men of varied social statuses and the various trades. They are enumerated in the name of seeking a jury to decide a debate between pride and lowliness personified respectively in the poem by velvet and cloth breeches..$^{11}$ Thynn details the honest clothes of bakers, vintners, merchants, tanners, bricklayers,

\footnotetext{
8 On Marx's own relation to the market in clothes, see Peter Stallybrass, "Marx's Coat", Border Fetishism s: Material Objects in Unstable Spaces, ed. Patricia Spyer (New York and London: Routledge, 1998), 183-207.

9 Edmund Spenser, The Complete Works of Edmund Spenser, ed. Edwin Greenlaw (Baltimore: Johns Hopkins University Press, 1949), X, 121. In the case of the theatre, clothes not only registered class distinctions, but made the boy a woman, and on early seventeenth-century London streets, sometimes apparently made a woman a man. See most recently Stephen Orgel, Impersonations: The Performance of Gender in Early Modem En gland (Cambridge: C.U.P., 1996).

${ }^{10}$ On sumptuary legislation, see Frances E. Baldwin, "Sumptuary Legislation and Personal Regulation in England", Johns Hopkins University Studies in Historical and Political Science 44 (1926); on livery, see Shammas, cited above; Satirical Songs and Poems on Costume in Early English Poetry, Ballads, and Popular Literature (London: Percy Society, 1849), vol. XXVII; the best single example of the Puritan attack on fashion is the frequently quoted Philip Stubbes, The Anatomie of Abuses in Ailgna of Philip Stubbes, ed. F. J. Furnivall (London, 1877-82); on State supported attacks on sartorial excess, see the frequently quoted "Homily against Excess of Apparel"; on the vestiarian controversy, see M. M. Knappen, Tudor Puritanism: A Chapter in the History of Idealism (Chicago: University of Chicago Press, 1939); Patrick Collinson, Godly People: Essays on English Protestantism and Puritanism (London: Hambledon Press, 1983) and his The Elizabethan Puritan Movement (Oxford: Clarendon, 1990). On fashions, status and gender more generally, see René Konig, The Restless Image, tr. F. Bradley (London: George Allen \& Unwin Limited, 1973) and J. C. Flugel, The Psychology of Clothes (London: Hogarth Press, 1930).

${ }^{11}$ See also A Pleasaunt Dialogue or Disputation Between the Cap and the Head (London: Henry Denham, 1565).
} 
shoemakers, weavers and husbandmen, but especially praises the knight, "plaine in his apparel" who "spends his living on the poorer sort" offering hospitality rather than wearing silk.12 The wearing of silk by the elite, he suggests, leads to destitution which he exemplifies in the poem by a woman and her children:

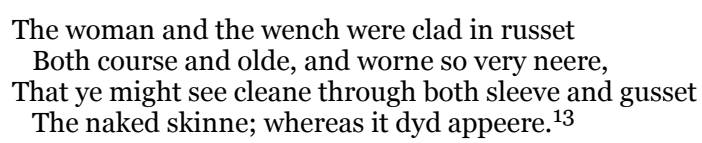

We learn initially that both the woman and her daughter are wearing russet, the coarse homespun woolen cloth of a reddish-brown, grey or neutral color used for the dress of peasants and country-folk (OED) already in the fourteenth century. ${ }^{14}$ But in Thynn's poem, the russet the woman and her daughter wear is so worn that their naked bodies can be seen through the threadbare fabric: "ye might see cleane through both sleeve and gusset". By specifying "gusset", originally a piece of flexible material that filled up a space under the arms at the joints between two adjacent pieces of mail, and subsequently a triangular piece of material let into a garment to strengthen or to enlarge the sleeve at the armpit to permit ease of movement (OED), Thynn glances ironically at the association of gusset with mail, since these poor persons' garments emphatically do not provide protection; but more importantly, in using this technical term-gusset-he suggests that their clothes are designed for utility, since the gusset was intended to provide ease of movement for labor. In the next stanza, he extends the paradoxical irony of russet so worn it is transparent when he observes the material and craftsmanship of their shoes and hose, only to reveal

\footnotetext{
12 On complaints about excess of dress and the decline of hospitality, see Joan R. Kent, "Attitudes of Members of the House of Commons to the Regulation of 'Personal Conduct' in late Elizabethan and Early Stuart England”, Bulletin of the Institute of Historical Research 46 (1973), 41-71. See also Felicity Heal, "The Idea of Hospitality in Early Modern England", Past \& Present 102 (1984), 66-93.

13 Francis Thynn, The Debate between Pride and Low liness, ed. J. Payne Collier (London: Shakespeare Society, 1841); in her research for The Great Reclothing of Rural England, Spufford was unable to find examples of ordinary clothing except for those excavated from a Shetlands bog. In other words, clothing in the period was worn to rags and then either exported for paper making abroad, or later, sold for paper making at home. See Coleman, cited above and the many examples in Shakespeare of "patches" as a substantive for the poorer sort.

14 On russet, see also Jones and Stallybrass, 229-44.
} 
that the leather he describes is none other than their weatherbeaten skin itself:

The hosen and their shooes were all of one

I meane both for the woorkmanshyp and leather,

To wye their skinnes, for other had they none,

And chapped were they sore with wind and weather.

The poorest in early modern England, then as now, were women and children who apparently wore almost nothing at all. Thynn's poem is not only allegorical homily, but sturdy social critique, for the poor woman and her children, we learn, had been "copie holders of tenant right". They have fallen on hard times after having been ousted by a rapacious "churle" to whom the lord / landowner has leased his land for cash. ${ }^{15}$

The relation of "condition" to apparel was also racialized in the early modern period with legislation to insure distinctions between the English and Irish and in attacks on the Irish mantle. ${ }^{16}$ In a contemporary song now titled "The Irish Hallaloo", the Irish are contrasted with their English betters in "Beavers and Castors so good": "when they are driven along the Passes / They've nothing but Tatters to hang on their Asses. / Instead of their Mantles lined with Plush: / They're forc'd to seek Rags off every Bush". ${ }^{17}$ The poor, it would seem, took their clothes wherever they could find them: from their masters as livery if they were fortunate enough to be employed, but if not, stolen as they dried on bushes and shrubbery, or even stripped from the bodies of the dead:

We beggars reck nought of the carcass of the dead body, but do defy it; we look for old cast coats, jackets, hose, caps, belts and shoes, by their deaths which in their lives the[y] would not depart from [...] god send me of them. ${ }^{18}$

\footnotetext{
15 For another contemporary critique of the effects of conspicuous consumption on the ploughman, see Middleton's Father Hubbard's Tales, or the Ant and the Nightingale (1604).

16 The Irish mantle was worn across social classes and most troublesome to many when it became fashionable among the English themselves. See Margaret Rose Jaster, "Fashioninge the Minde and Condicions': The Uses and Abuses of Apparel in Early Modern England”, (Diss. University of Maryland, 1994) and Jones and Stallybrass, cited above.

${ }^{17}$ D’Urfey's Songs Compleat Pleasant and Divertive: Set to Musicke (London: W. Pearson for J. Tonson, 1719), Vol. IV, 199-200.

18 Quoted from W. Bullein, A Dialogue against the Pestilence (1593) by Woodward, 79, cited above.
} 
Whereas the poor sought clothing for the sake of modesty or to protect themselves from weather, for the better off dress maintained status distinctions, enabled social mobility and social emulation, and provoked anxiety about sartorial trespass. Whether in city comedy, personal letters and diaries, sermons or other genres, contemporaries satirized persons who dressed above their station and bemoaned the decline of the landed elite through the sale of land for the purchase of high fashion. ${ }^{19}$ In the anonymous play Thomas of Woodstock, which dramatizes Richard II's history from the perspective of his uncles, and particularly as its title indicates, that of Thomas of Woodstock, Duke of Gloucester, clothing both plain and extravagant is central to the play's rhetoric and presentation of character. Woodstock is explicitly characterized from the outset by his refusal of the "braverie" worn by others of his rank, and most importantly, by Richard's ambitious minions. He is introduced as Plain Thomas, so named, we learn,

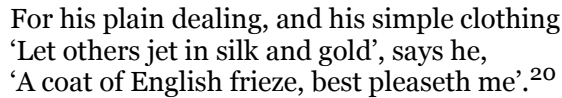

Here the rhyme paradoxically distinguishes Woodstock's plain speech from the unrhymed pentameter of his brothers and establishes the contrast between Richard and his gaudily dressed favorites, and Thomas of Woodstock's "country habit" (I.i.197), "t'other hose" and "frieze coat" (I.iii.100-1). "Frieze", like russet, is also a coarse woolen cloth, but with a nap. Woodstock rehearses the standard Elizabethan and Jacobean anxiety that land is being razed, sold and worn on the shoulders of the elite: "A hundred oaks upon these shoulders hang / To make me brave upon your wedding day, / And more than that, to make my horse more tire, / Ten acres of good land are stitched up here" (I.iii.95-98). In the conventional trope, generic forests are razed to pay for fashionable attire, but here, the choice of oaks, long associated with

\footnotetext{
19 On clothing and the elite, see Lawrence Stone, cited above; for a concise consideration of dress, status and social mobility, see Lisa Jardine, Still Harping on Daughters (Sussex: Harvester, 1983), 141-168, but for a cautionary word about the pre-occupation with "emulation" in work on consumer behavior and dress later in the period, see Lorna Weatherill, cited above. See also my Fashioning Femininity and English Renaissance Dram a and Jones and Stallybrass, cited above.

${ }^{20}$ Thom as of Woodstock or Richard the Second, Part One, eds. Peter Corbin and Douglas Sedge (Manchester: Manchester University Press, 2002), I.i.99-102. All references are to this edition.
} 
England and its kings, and explicitly with Richard later in the play (II.i.21; Iv.iii.181), emphasizes not just the cost of fashion to an individual estate, but its cost to the nation: Woodstock's wedding bravery, his "golden metamorphosis / From homespun housewifery" (75-6) as Richard dubs it, may even fell its king. But Woodstock, like Thynn's knight, sees that cost not so much in terms of a struggle between Crown and peerage, or its symbolic cost to the nation, but in material, if paternalistic terms, to its people. When the king and his favorites mock his t'other hose and frieze coat, he responds:

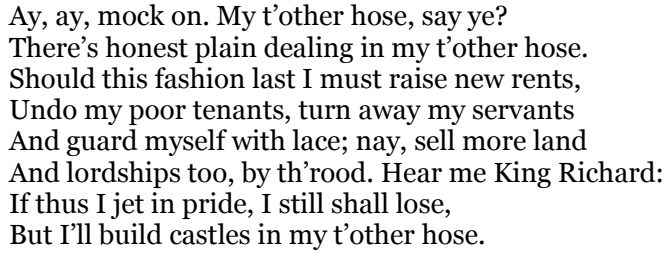

When the Queen demurs that the king but jests, Woodstock's rejoinder is explicit: "T'other hose! Did some here wear that fashion / They would not tax and pill the commons so!" (111-12), and he repeats that accusation later when Richard chides him for shedding his "golden rich habilements" donned in honor of the king's wedding and the coronation of his queen. Richard's blank charters and exploitation of the commons are the cost of fashion and excess in apparel, an equation set up again later in II.iii when the Queen turns her jewels and plate into coin to help "seventeen thousand poor and indigent" and commands trunks "of needful clothing / To be distributed amongst the poor" (20, 59-60).

Not only material want, but moral qualities and political behaviors are insistently characterized in terms of clothes and cloth: Woodstock's "mind suits with his habit / Homely and plain" (I.i.10607), his heart is likened to "plain frieze", and his judgments are "homespun". Tressilian, the ex-lawyer, pledges he will make law "most suitable to all your pleasures" (48). Though "suitable" clearly means fitting and appropriate, in the context of the play's reiterated language of dress, it plays on "suit" in all its myriad meanings in early English drama: suit of clothes, suit at law, suing or pleading, even a lover's suit or courtship. The play on "suit" is presented most emphatically at the 
end of II.iii where the King's council spends its time devising new, foreign fashions rather than managing English affairs of state:

They sit in council to devise strange fashions,

And suit themselves in wild and antic habits

Such as this kingdom never yet beheld:

French hose, Italian cloaks, and Spanish hats,

Polonian shoes with peaks a hand full long,

Tied to their knees with chains of pearl and gold.

Their plumed tops fly waving in the air

A cubit high above their wanton heads.

A few lines later, Richard reiterates "We held a council to devise these suits" (III.i.47-48, 51) and this riot of fashion makes of the king's favorites "four kings more". In Thomas of Woodstock, apparel distinguishes the nobility, with the exception of Woodstock, from the vulgar, and from the vulgar fashions of England, but it also breaks down the difference between anointed king and his plebeian favorites.

Thomas of Woodstock is usually dated 1591-94 and has generally been thought to be a source for Shakespeare's play. ${ }^{21}$ Recently commentators have claimed the play represents a "far more important source for Richard II than critics have acknowledged" and that it "speaks both through what remains of it in Richard II, and through what Shakespeare left out or modified". ${ }^{22}$ At II.i, of Shakespeare's play when Gaunt chastises the king, he dubs his brother Gloucester "plain" echoing the anonymous Woodstock. Richard II opens famously with Bolingbroke's staged challenge to Mowbray and accusation that "he did plot the Duke of Gloucester's death". Though critics have long observed that Mowbray's response to that accusation is difficult to follow, and that the references to Richard's part in the murder of Woodstock have been said to be vague, inconclusive, and

\footnotetext{
${ }^{21}$ Rossiter lays out the parallels in the introduction to his edition, Woodstock. A Moral History, ed. A. P. Rossiter (London: Chatto \& Windus, 1946).

22 Paula Blank, "Speaking Freely about Richard II", JEGP 96 (1997), 327-348. For a countervailing view, see MacD. P. Jackson, "Shakespeare's Richard II and the anonymous Thomas of Woodstock", Medieval and Renaissance Drama in England 14 (2001), 17-65. Drawing on various empirical studies of the British Library manuscript in which Woodstock is preserved, he argues that Woodstock is an early seventeenth-century play based on Shakespeare rather than one of his sources. It remains to be seen whether Jackson's exhaustive argument concerning the date of the anonymous Woodstock will be widely accepted, but my argument does not depend on which play pre-dates the other.
} 
ambiguous, ${ }^{23}$ recently commentators have argued for the importance of the murder, and the anonymous play that dramatizes it, to Shakespeare's play and its Elizabethan audience.

But unlike the anonymous Thom as of Woodstock, Shakespeare seems deliberately to avoid description of Richard's sartorial excess. Whereas Woodstock emphasizes the sartorial extravagance of Richard and his minions in contrast with plain Thomas's frieze coat and t'other hose, the buckram of Nimble, and of Tresilian in his lawyer days, Shakespeare makes reference instead to specific items of clothing and emblems of kingship to highlight their symbolic significance: Bolingbroke's bonnet, with which we began, the gloves or gages of Mowbray and Bolingbroke at the play's ceremonial beginning and in v.iii, the royal sceptre, and most famously, Richard's contested crown. Though Shakespeare makes mention of "gay apparel”, with Woodstock dead before the action of Richard II opens, he doesn't rely on or develop the contrast of Gloucester's plain style with that of the king and his favorites central to the anonymous Thomas of Woodstock. In Richard II "gay apparel" figures differently. Instead of opposing plain Thomas to gaudy Richard, Shakespeare, as generations of critics have noted, presents two Richards, the King Richard of the first half of the play who, even on his initial return from Ireland imagines his bright sun will pluck the "cloak of night" from off the back of "murders, treasons and detested sins". That Richard, who calls attention to his "gay apparel" which, as we have noted, he offers to trade for an "almsman's gown", is contrasted with the self-reflective Richard, the so-called poet king of the second half of the play who divests himself of the material emblems of kingship until he is finally alone in prison, unaccommodated man, his only "suit" his words. ${ }^{24}$

The phrase "gay apparel" appears in another context in the play as well, in the subplot involving Aumerle's treason. At Act v.ii, the Duchess of York attempts to hide her son's treason from his father by claiming the treasonous letter plotting Bolingbroke's assassination is no more than a contract for "gay apparel" for the new king's

23 Larry Champion, "The Functions of Mowbray: Shakespeare's Maturing Art in Richard II", SQ 26 (1975), 3-7; Richard II, ed. J. Dover Wilson (Cambridge: C.U.P., 1939), lxviii; E. M. W. Tillyard, Shakespeare's History Plays (New York: Macmillan, 1946); and A. P. Rossiter, cited above.

${ }^{24}$ For a concise review of Richard as "bad king, good poet", see Madhavi Menon,

"Richard II and the taint of Metonomy", ELH 70 (2003), 653-675. 
coronation: "Tis nothing but some band that he is entered into / For gay apparel "gainst the triumph day" (65-66). Here the Duchess substitutes "gay apparel" for treason, just as in the anonymous Woodstock sartorial extravagance is equated similarly with treason. When York reads the supposed bond for gay apparel and discovers the plot, it prompts his own call for apparel: "Give me my boots" (77), he cries, "Bring me my boots" (84) he repeats, and then again, "Give me my boots, I say" (87), to almost comic effect.

In Thom as of Woodstock, when Woodstock is imprisoned and about to be murdered, he writes to his nephew admonishing him "to govern like a virtuous prince" (v.i.187). In this invocation of the genre of "advice to a prince", Plain Thomas's homeliness is no longer his dress, but style: "I know not what to write, / What style to use; nor how I should begin. / My method is too plain to greet a king" (206-08). Not only English and continental Renaissance drama and poetry, but countless classical, medieval and early modern treatises concerned with rhetoric draw upon such comparisons of rhetoric and style to dress: the argument is the body, the figures of speech or rhetoric, its clothing or ornament. As Edmund Bolton puts it in his 1610 treatise The Elements of Armories, implying an analogy as well between rhetoric and armor, "Style" is "the apparel of matter". Perhaps the best known Shakespearean example is the insistently ironic and often quoted moment in Love's Labour's Lost, when Berowne promises "By this white glove", to forsake "Taffeta phrases, silken terms precise / Three-pil'd hyperboles" in favor of "russet yeas and honest kersey noes". To demonstrate his sincere adoption of russet and kersey, the cloth / style of the poor, in the following two lines he dubs Rosaline "wench", and swears ("so God help me law"), but nevertheless ends his amorous avowal by betraying his newly embraced plain style: his love, he vows, is "sans crack". Rosaline is quick to counter, "Sans 'sans', I pray you”, objecting to his use of French. Berowne's promised russet and kersey is framed by two signs of his membership in a fashionconscious, educated elite: the white glove and the French "sans", doubly ironic since Shakespeare's English speaking lords waiting on the King of Navarre should presumably, of course, be speaking French. Berowne's spruce taffeta, silk and velvet suit to Rosaline fails and he is banished to try his dressy wit instead on sickly ears. 
Clothing and ornament, as many commentators have observed, makes the body culturally visible. ${ }^{25}$ Even the female nude in the history of western art "has always assumed the form dictated by contemporary fashion". ${ }^{26}$ As one commentator has argued:

Clothing exercises as profoundly determining an influence upon living, breathing bodies as it does upon their literary and cinematic counterparts, affecting contour, weight, muscle development, posture, movement and libidinal circulation. Dress is one of the most important cultural implements for articulating and territorializing human corporeality. ${ }^{27}$

In early modern England, as Jane Ashelford observes in her work on Dress in the Age of Elizabeth I, elite fashion shaped and molded the body in order to display an "elongated, tapering waist, wide circular ruff and swollen hips and arms common to both sexes". ${ }^{28}$ Doublets and hose were shaped and fitted to bodies, and padding of various kinds emphasized the contrast between parts of the body, legs, crotch and torso in the case of men, torso and hips in the case of women. ${ }^{29} \mathrm{But}$ Ashelford ignores the clothing of the poor, which by contrast was typically coarsely cut, shapeless, sometimes loosely belted or buttoned garments with an open knee length shirt and loose fitting pants for men, skirts for women, that produced an undifferentiated body, a body whose shape could barely be discerned. Instead of gloves that articulated the fingers of the hand, the poor wore mittens and clogs rather than shoes or boots. As clothing began in the course of the seventeenth-century to be available for purchase "ready to wear" rather than bespoke, sizing was a slowly introduced innovation. ${ }^{30}$ Since clothing, including its color and cut, was often dictated to the servant,

\footnotetext{
25 Silverman, drawing on the work of Eugénie Lemoine-Luccioni, La robe: essai psychanalytique sur le vêtem ent (Paris: Éditions du Seuil, 1983).

${ }^{26}$ See Ann Hollander, Seeing Through Clothes (New York: Viking, 1975): "The placement, size, and shape of the breasts, the set of the neck and shoulders, the relative girth and length of the rib cage, the exact disposition of its fleshly upholstery, front and back-all these, along with styles of posture both seated and upright, are continually shifting according to the way clothes have been variously designed in history...” 91, quoted in Silverman.

27 Silverman, 146

28 Ashelford, 43, cited above.

${ }^{29}$ On the codpiece, for example, see Marjorie Garber, "Fetish Envy", October 54 (1990), 45-56.

30 See John Styles, "Product Innovation in Early Modern London", Past \& Present 168 (2000), 124-169; on sizing see his "Clothing the North", cited above, $161 \mathrm{ff}$.
} 
laborer or apprentice contractually as part of livery, style was the province of the elite; the poor were denied what social historians have termed "consumer sovereignty". ${ }^{31}$ The pursuit of fashion so often noted in the early modern period, whether in sumptuary laws and their transgression, or in the pursuit of foreign fashions and the extravagant spending of the elite, records social aspiration.

In their important, wide-ranging study of Renaissance clothing, Ann Rosalind Jones and Peter Stallybrass insist on the constitutive power of dress not only for the subject, but for the body politic. The putting on of clothes or investiture was constitutive, "the means by which a person was given a form or shape, a social function, a 'depth". 32 In his third anti-theatrical satire in Book I of Virgidemiarium (1598), Joseph Hall highlights this relation between dress and social function in the context of theatre: "A goodly hochpoch", he observes, "when vile Russettings, / Are match't with monarchs, \& with mighty kings". Hall's attack on actors, referred to metonymically by their russet clothing, actors who play the more opulently dressed parts of their betters, may also allude to the perceived danger of representations on the English stage of kings as beggars. 33 In Thom as of Woodstock, as we have seen, when Gloucester is imprisoned and about to be murdered, he would seem to be enjoying the privileges of elite prisoners in the period: he seems to be wearing the frieze coat and t'other hose he has worn virtually throughout the play; he has access to implements for writing; and he seems to sit musing about how to "dress" his advice to the king at some piece of furniture on stage.

But at the end of Shakespeare's Richard II we find Richard not merely bereft of kingly crown and sceptre, but seemingly dressed in the rags of a beggar, bereft of that apparel which marks him / makes him, a king. At Act V.v, Richard famously studies how to compare his prison to the world, and finds he cannot do it. His thoughts and doubts plot

\footnotetext{
${ }^{31}$ Shammas, cited above.

32 Jones and Stallybrass, 2.

33 See David Kastan, "Proud Majesty Made Subject: Shakespeare and the Spectacle of Rule", Shakespeare Quarterly 37 (1986), 459-75 and William C. Carroll, Fat King, Lean Beggar: Representations of Poverty in the Age of Shakespeare (Ithaca: Cornell University Press, 1996).
} 
Though certainly commentators, including the editors of the Arden and Norton Shakespeares, are right to gloss "ragged" as rugged, in keeping with "flinty" and "prison walls", "nails" and "ribs" also invoke another network of images. They suggest that Richard alludes as well to the little world of man, to his own body clothed in nothing but beggarly rags which he would rend to escape the self as "seely beggar", whom the audience witnesses on stage, in the stocks bearing his "misfortunes on the back" (29)

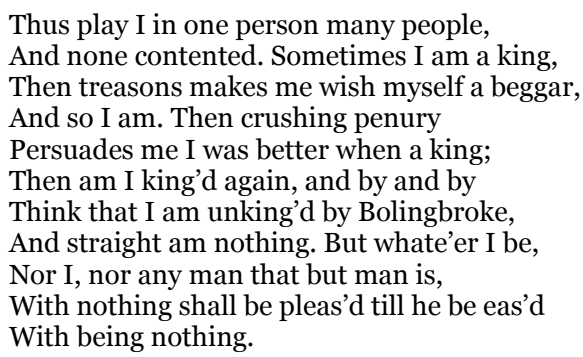

Crushing penury, as we have seen, meant rags and nakedness. As potentially seditious as the deposition scene itself when the king relinquishes crown and sceptre, the representation of Richard in rags, as a beggar alone, imprisoned in the little world of Pomfret Castle, without the boots and gloves and gay apparel of the elite, without the crown and sceptre of a king, with only his suit of words, this last scene of Richard II may have offered an equally forceful enactment of peril to the body politic.

The putting on of clothes or investiture was constitutive: to reiterate Jones and Stallybrass: it is "the means by which a person was given a form or shape, a social function, a 'depth" (2). They rightly debunk notions of clothing as mere surface, notions which they acknowledge rest on philosophically suspect oppositions between surface and depth, inside and outside. In recognizing the constitutive force of dress and in rehabilitating the study of material culture and of objects, they go on to claim that our "interest in objects (including clothes) is characterized by disavowal" (10) arising out of the continuing power of such suspect oppositions. While recognizing the 
force of Jones' and Stallybrass's claim, we need to think critically about the pre-occupation with early modern conspicuous consumption and elite fashion, with the silks and velvets, plush and embroidery, lace and starch, that has characterized work on fashion and clothing in early modern England, including my own. That pre-occupation also speaks to what Jean Baudrillard and others have analyzed as our compulsion to serve the market, to enjoy the "fun system" of consumption. ${ }^{34}$ It bespeaks our own interpellation into a political economy that prompts not only a staggering consumer debt compounded through the exercise of desires that may not be our own, but also a cultural studies that too often abandons critique to collaborate fully with commodity fetishism.

Karen NEWMAN New York University

34 In claiming that our relation to objects is characterized by "disavowal", Jones and Stallybrass write against the critique of objects mounted by Jean Baudrillard's series of books on objects and consumption, Le système des objets (Paris: Gallimard, 1968); La société de consommation, ses mythes, ses structures (Paris: SGPP, 1970); Simulacres et Sim ulations (Paris: Galilée, 1981); and Les stratégies fatales (Paris: Grasset, 1983). 